\title{
Shockwave Overpressure of Propellant Gases Around the Mortar
}

\author{
Miodrag Lisov ${ }^{1)}$ \\ Slobodan Jaramaz ${ }^{2)}$ \\ Mirko Kozic ${ }^{1)}$ \\ Novica Ristović ${ }^{1)}$
}

\begin{abstract}
This paper is a result of many years of research in the field of the powder gases shockwave overpressure, which occurs during firing from the mortar. The cause of these occurences is a sudden flow of powder gases from the weapon barrel and its expansion in the undisturbed environment. In this paper, an influence of a propellant charge on the overpressure intensity of the shockwave produced by powder gases nearby mortar is shown. The research comprised modelling and computation of the overpressure field around the weapon, in order to determine its intensity and distribution in space and time. With the aim of the real description of the mentioned occurences, the theoretical part was given, and then the numerical modelling of the instantaneous flow of the powder gases from the motrar barrel has been conducted. Experimental results are obtained from the firing experiments with the $120 \mathrm{~mm}$ mortar. Computation and experimental results are given in the form of a chart of the barrel pressure change and overpressure of powder gases, at the characteristic measuring points around mortar.
\end{abstract}

Key words: gas dynamics, the gas flow process, powder charge, powder gases, overpressure, shockwave, pressure influence, mortar, interior ballistics, experimental results.

\section{Introduction}

$\mathrm{T}$ HE need for the increase in the maximum range, which is mostly achieved by improving aerodynamic characteristics of the missile, and by the construction changes of the weapon, also leads to the use of greater, and actually more powerful powder charges. A more powerful powder gases, as a consequence, have an increase in the operation pressure in the weapon barrel, and the greater production of the powder gases, which leads to the increase in the overpressure around the weapon. As a consequence there is the occurrence of the greater overpressure around the weapon, which is particularly emphasized at the mortar, where the firing operator (gunner) is in the vicinity of the weapon during the procedure of loading and firing [1]. Everything mentioned imposes the need of defining an influence of the weight increase of a propellant charge on overpressure intensity of a nearby mortar's shockwave.

Theoretical basis is set up and mathematical modelling is done, as well as computation of characteristic gas dynamic values [3].

For the verification of the applied numerical model [4], the experimental measuring method was used.

\section{Theoretical basis}

With the aim of resolving complex gas dynamics phenomena, Computational fluid dynamics (CFD) with finite volume method (FVM) is used, in order to enable the use of the unstructured mash and simple use of Neumann's boundary condition.

In theory, the following equations are used:
Conservation of mass:

$$
\frac{\partial \rho}{\partial t}+\left(\rho v_{i}\right)_{, i}=0
$$

Conservation of momentum:

$$
\rho \frac{\partial v_{j}}{\partial t}+\rho v_{j, i} v_{i}+p_{, j}-\tau_{i j, i}+\rho F_{j}=0
$$

Conservation of energy:

$$
\rho \frac{\partial e}{\partial t} \rho e_{, i} v_{i}+p v_{i . i}-\tau_{i j} v_{j, i}+q_{i, i}-\rho r=0
$$

Where $\rho$ is the fluid density, $v_{i}$ - components of the velocity vector components, $e$ - internal energy per unit mass, $F_{i}$-components of body force vector volume, $p$ - pressure, $\tau_{i j}$ - viscous stress tensor, $T$ - temperature, $q_{i}$ - heat flux and $r$ heat supply per unit mass.

Navier-Stokes set of equations in the so-called conservation form [5], [6]:

$$
R=\frac{\partial U}{\partial t}+\frac{\partial F_{i}}{\partial x_{i}}+\frac{\partial G_{i}}{\partial x_{i}}-B
$$

Where: $U$ is conservative flow variables vector per unit volume, $F$ is convective flux variable vector, $G$ is diffusion flux variable vector, and $B$ is a source term (mass, momentum and energy).

In the process of numerical simulation, in the exit cross section, on the muzzle, an equation of pressure change with time defined as in Eq. (5) is used:

\footnotetext{
1) Military Technical Institute (VTI), Ratka Resanovića 1, 11132 Belgrade, SERBIA

2) University of Belgrade, Faculty of Mechanical Engineering, Kraljice Marije 16, 11020 Belgrade 35, SERBIA

Correspondence to: Mirko Kozić; e-mail: mkozic@open.telekom.rs
} 


$$
p=p_{p} e^{-K t}
$$

Where $K$ is coefficient for barrel, $p$ is pressure, $p_{p}$ is the initial pressure and $t$ is time.

Temperature change is defined in equations (6) and (7):

$$
\begin{gathered}
m r \frac{1}{T} \frac{\partial T}{\partial t}=\frac{1}{p} \frac{\partial p}{\partial t} \\
T=T_{p}\left[\frac{p}{p_{p}}\right]^{\frac{1}{k}}
\end{gathered}
$$

\section{Gas dynamics calculations}

Numerical simulations provide preconditions which, by computation, enable reaching the characteristic values of the gas flow, which sets free in the firing process. The belonging physical appearances are simulated in the proposed mathematical model, and the condition of the gas phase of the combustion products and the surrounding air may be monitored in space and time. This way the shock wave front, which moves through the space, causing the change of the condition in the undisturbed environment, is clearly noticed.

Numerical computation was conducted on the basis of the proposed mathematical model and realized by software ANSYS FLUENT, where the averaged Navier-Stokes equations are solved [9].

Used dynamic mesh adaption [11] is based on the pressure gradient, because of its very high value near the shock.

In Fig. 1 a scheme with characteristic measuring places that correspond with an actual position of crew members is given.

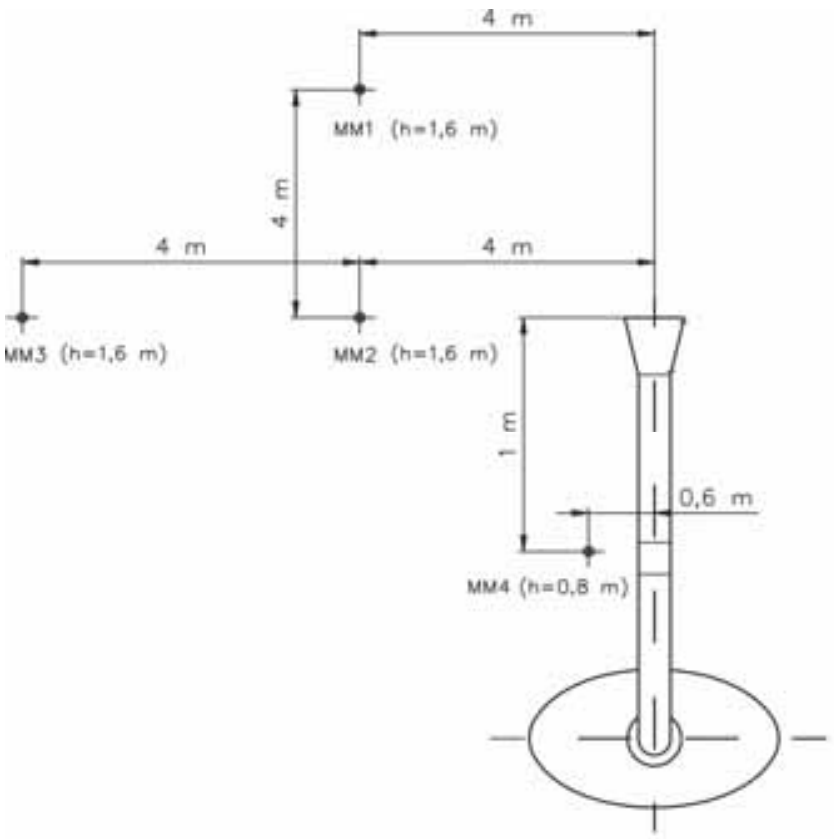

Figure 1. Measuring point's scheme

The results of the numerical calculations of the overpressure versus time, calculated for characteristic measuring points MM1, MM2 and MM3, for $120 \mathrm{~mm}$ mortar firing are given in Fig. 2.

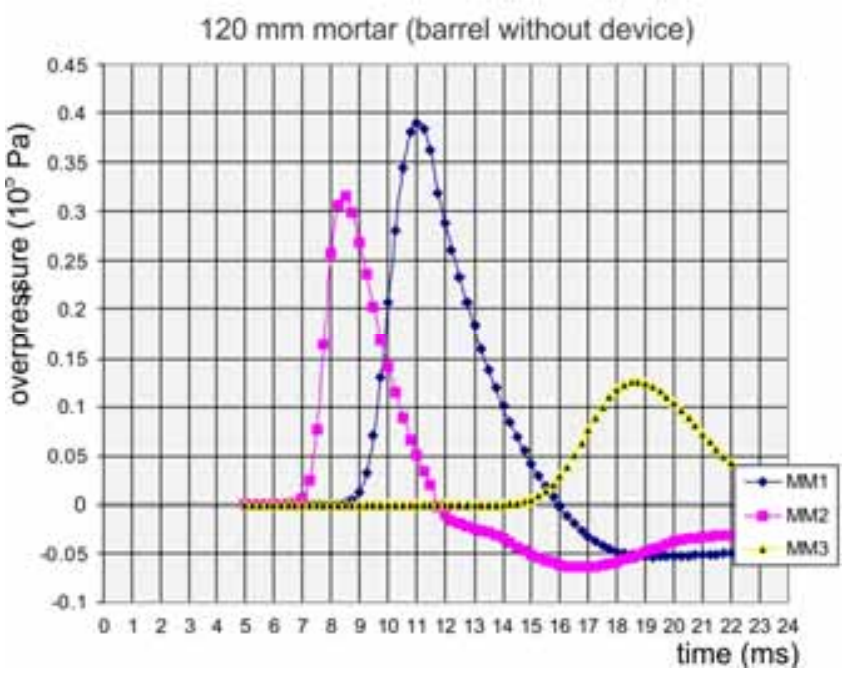

Figure 2. Gas dynamic computation (2D),

In Fig. 3 visualized results of the numerical calculations for the gas flow characteristics captured in characteristic moment are shown.

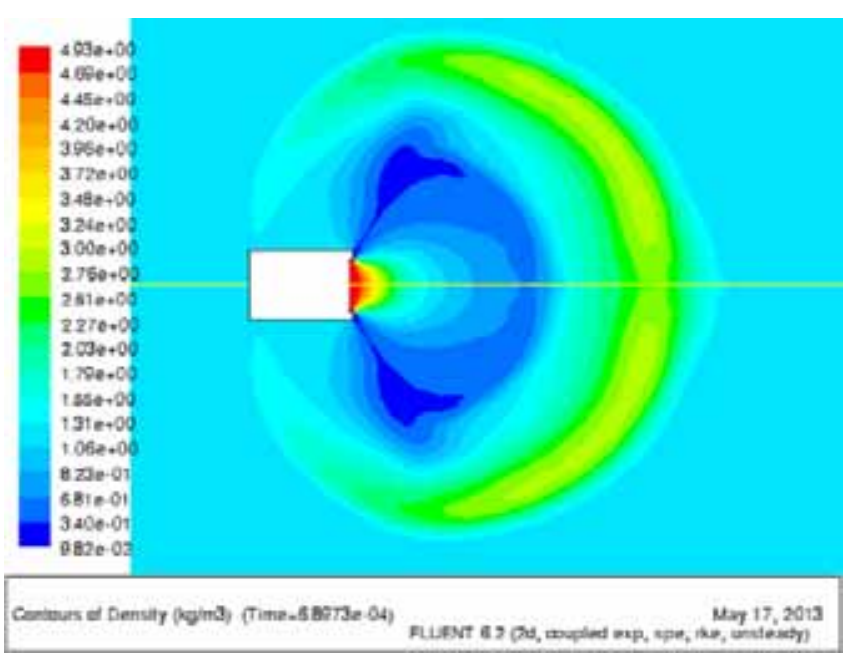

a) Gas density

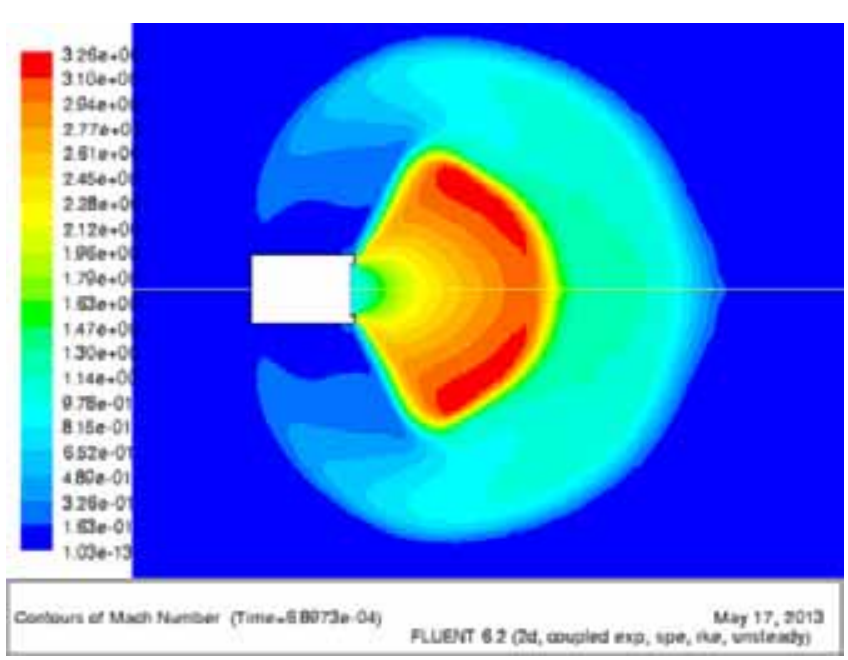

b) Mach number 


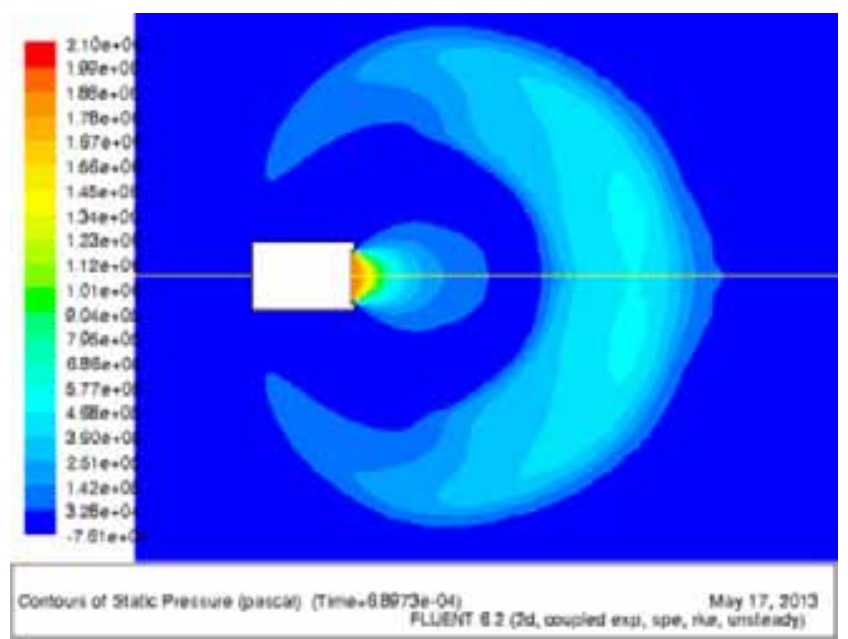

c) Gas pressure

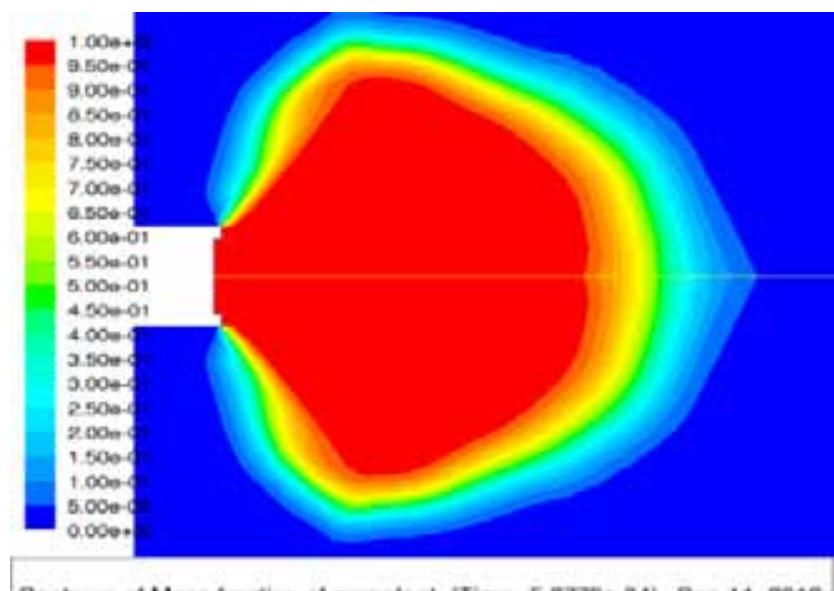

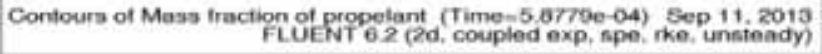

d) Concentration of propellant gases

Figure 3. Results of gaseous dynamics calculations

\section{Interior ballistics calculations}

Interior ballistics calculations are done for the case of firing $120 \mathrm{~mm}$ lightweight high explosive shell (LTF), propellant charges $\mathrm{O}+6$ (ignition charge +6 increment charges), $\mathrm{O}+7$ (ignition charge +7 increment charges) and new extended range $120 \mathrm{~mm}$ mortar shell with propellant charge $\mathrm{O}+10$ (ignition charge +10 increment charges).

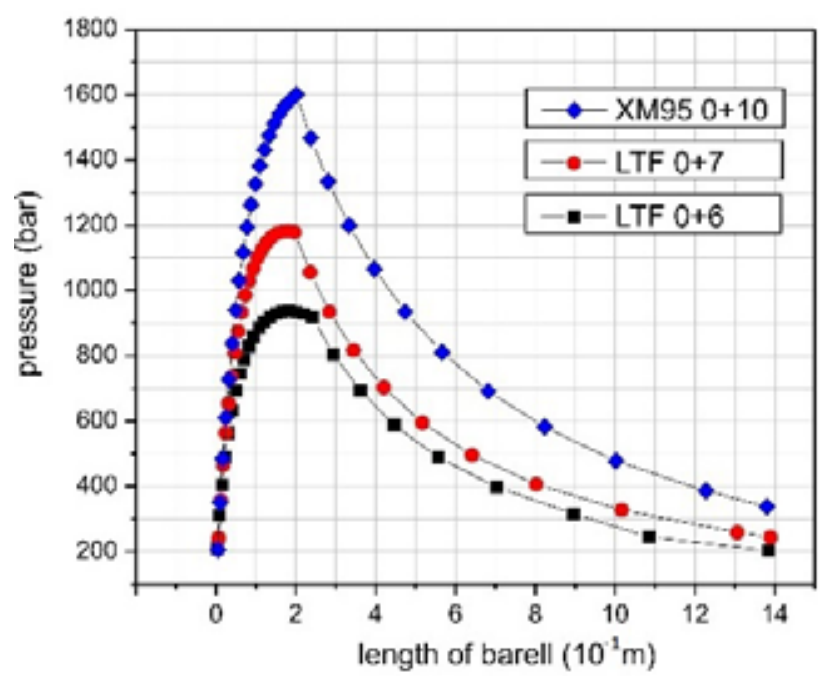

Figure 4. Comparative overview of pressure versus barrel length for firing $120 \mathrm{~mm}$
Interior ballistics calculations are done for the three presented cases, using the software which performs calculations by simplified Serebryakov method. Pressure versus time curves $(p-t)$, i.e. pressure calculations for the three presented examples are given in Fig.4.

For lightweight shell $120 \mathrm{~mm}$ LTF, a standard propellant charge $(\mathrm{O}+6)$ and a charge for safety check at extreme barrel pressure $(\mathrm{O}+7)$, with double based propellant was used. For extended range mortar shell $120 \mathrm{~mm}$ XM95, a new propellant charge, which is also double based, but with different characteristics was used.

Input data for interior ballistics calculations are given in Table 1.

Tabe 1. Input data for interior ballistics calculations

\begin{tabular}{|c||c|c|c||}
\hline Mortar $120 \mathrm{~mm}$ & M95 & M95 & M95 \\
\hline Shell $120 \mathrm{~mm}$ & LTF & LTF & XM95 \\
\hline Propellant charge & $(\mathrm{O}+6)$ & $(\mathrm{O}+7)$ & $(\mathrm{O}+10)$ \\
\hline Shell weight & $12,6 \mathrm{~kg}$ & $12,6 \mathrm{~kg}$ & $15,6 \mathrm{~kg}$ \\
\hline Weight of ignition charge & $0,032 \mathrm{~kg}$ & $0,032 \mathrm{~kg}$ & $0,040 \mathrm{~kg}$ \\
\hline Weight of increment charge & $0,456 \mathrm{~kg}$ & $0,532 \mathrm{~kg}$ & $0,810 \mathrm{~kg}$ \\
\hline
\end{tabular}

\section{Experimental results}

Experiment was realized by firing from the $120 \mathrm{~mm}$ mortar. The overpressure values at the characteristic measuring points around the weapon barrel were measured with the PCB sensors, as shown in Fig.5. Used sensors are PCB Piezotronics mod. 137A24, with measuring range of up to 17.27 bars and sensitivity of $20 \mathrm{mV} / \mathrm{psi}$.

The results of the experiment, measured during the process of firing several groups of shells are given in the Table 2.

Tabe 2. Results overview for firing mortar shells $120 \mathrm{~mm} \mathrm{LTF}$ and XM95

\begin{tabular}{|c|c|c|c|c|c||}
\hline$V_{o}$ & $P m$ & $\Delta p$ MM1 & $\Delta \mathrm{p} \mathrm{MM2}$ & $\Delta p$ MM3 & $\Delta \mathrm{p} \mathrm{MM4}$ \\
\hline$(\mathrm{m} / \mathrm{s})$ & $($ bar $)$ & $($ bar $)$ & $($ bar $)$ & $($ bar $)$ & (bar) \\
\hline \hline \multicolumn{7}{|c||}{$120 \mathrm{~mm}$ LTF doublebased propellant 456g (0+6) } \\
\hline 322,0 & 846 & 0,18 & 0,12 & 0,06 & 0,17 \\
\hline \hline \multicolumn{7}{|c|}{$120 \mathrm{~mm}$ XM95 doublebased propellant 567g (0+7) } \\
\hline 325,8 & 836 & 0,20 & 0,17 & 0,08 & 0,24 \\
\hline \hline \multicolumn{7}{|c|}{$120 \mathrm{~mm}$ XM95 doublebased propellant 810g (0+10) } \\
\hline 399,2 & 1401 & 0,30 & 0,26 & 0,10 & 0,32 \\
\hline
\end{tabular}

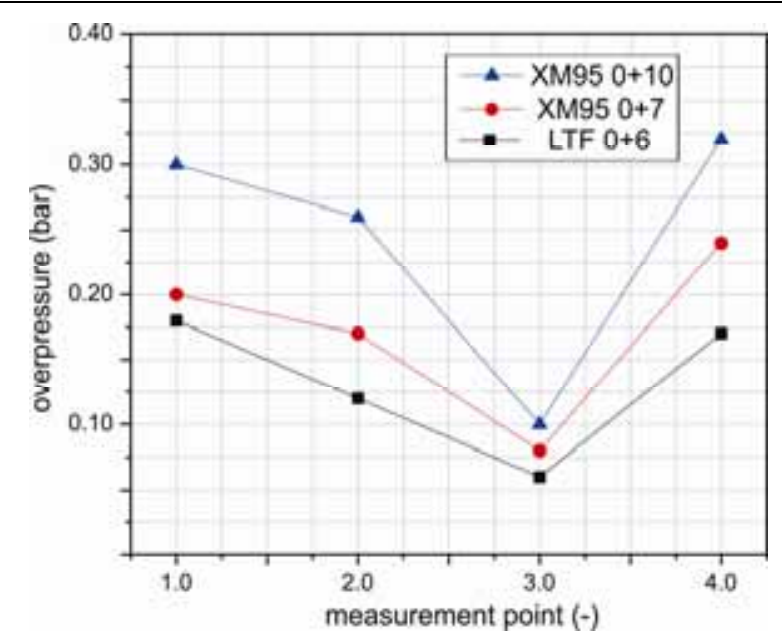

Figure 5. Results overview for measured overpressure around weapon for firing $120 \mathrm{~mm}$ shells LTF and XM95 


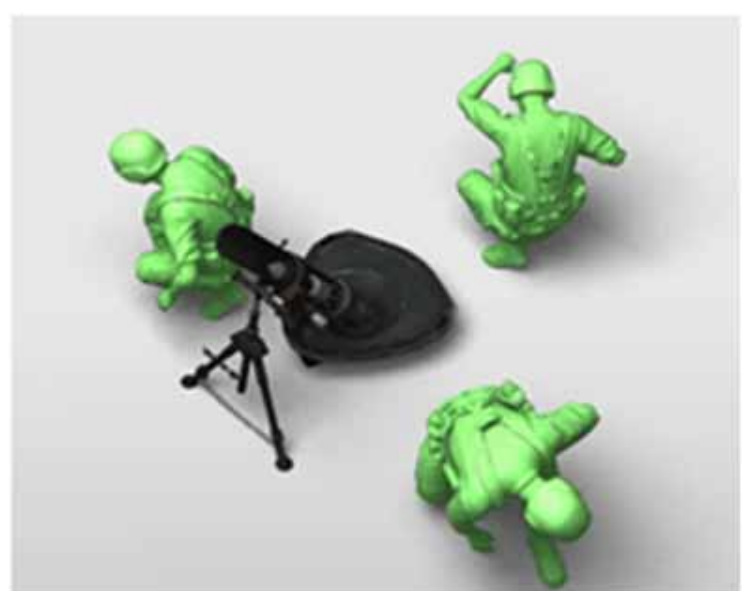

Figure 6. Display of mortar crew during the firing process (measuring point MM4 is actual gunner's position)

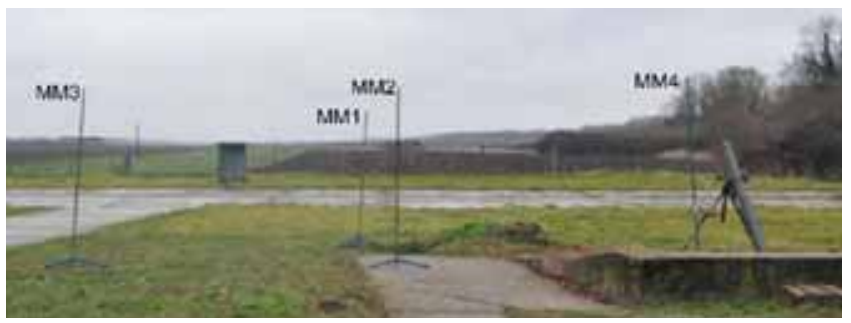

Figure 7. Display of measuring points for overpressure measuring around $120 \mathrm{~mm}$ mortar

\section{Result analyses}

Generally, the results obtained with a gas dynamic computation (2D), are fully satisfying, as confirmed by the experimental results that are measured during firing and presented in Fig.8. In the available literature [14], there is a fact stated that the model of gas dynamic computation (2D) with the cylindrical shockwave is of a the greater overpressure value in comparison with the sphere shockwave which has been confirmed in this case.

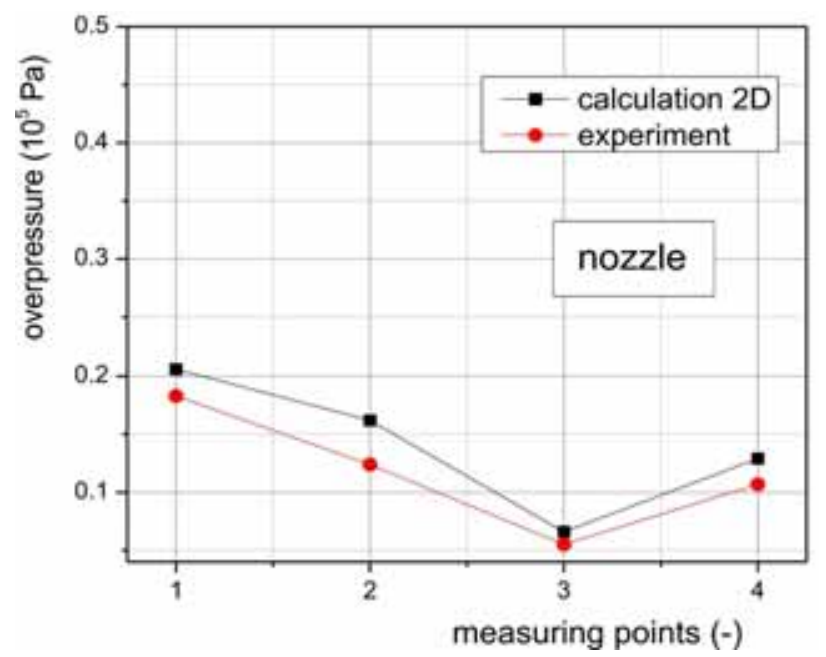

Figure 8. Overpressure computation and experimental results, $120 \mathrm{~mm}$ M95 mortar with LTF M62P1 and $(\mathrm{O}+7)$ propellant charge

\section{Conclusion}

On the basis of the conducted analysis, the computational results, and experimental testing with the $120 \mathrm{~mm}$ mortar system with applied construction solutions following conclusions were made:

- gas dynamics computations, with 2D numerical simulation, showed that the proposed mathematical model, with the applied software that used the adaptively generated mesh, determines the position and shockwave strength accurately and precisely enough, as shown in Fig.8,

- proposed mathematical model and applied numerical simulation gives 3D presentation of gaseous dynamics parameters of gas flow (velocity, density, pressure and concentration) which can be observed in different time intervals and different points in space around the weapon, - with propellant charge $\mathrm{O}+10$, which provides maximum velocity of $400 \mathrm{~m} / \mathrm{s}$, the overpressure at the gunner's position is $\Delta \mathrm{p}=0,32$ bar, which requires the use of protective equipment and imposes the need of reducing the overpressure, because the overpressure of $0,30 \mathrm{bar}$ and more is considered to be the one that may cause issues and disturbance of mortar crew.

\section{References}

[1] RONČEVIĆ,R., JEZDIMIROVIĆ,M., LISOV,M., BRKUŠANIN,A.: Future Mortars Systems. $5^{\text {th }}$ International Scientific Conference on Defensive Technologies OTEH 2012, 18-19 September 2012, Belgrade, Serbia, ISBN 978-86-81123-58-4, pp.260-266.

[2] TAYLOR,T.D.: Calculation of Muzzle Blast Flow Fields. PA-R-4155, Picatinny Arsenal, Dover, N. J., 1970.

[3] ROE,P.L.: Approximate Riemann solvers, parameter vector, and difference schemes. Journal of Computational physics, 1981, Vol.43, No. 2, pp.357-372, DOI: 10.1016/0021-9991(81)90128-5.

[4] KOZIĆ,M.: (2013). Application of Computational Fluid Dynamics in Aeronautics. Military Technical Institute, Belgrade.

[5] BEAM,R.M., WARMING,R.F.: An Implicit Factored Scheme for the Compressible Navier-Stokes Equations. AIAA Journal, 1978, Vol. 16, No.4, pp.393-402, DOI: 10.2514/3.60901.

[6] SICLARI,M., JAMESON,A.: A Multigrid Finite Volume Method for Solving the Euler and Navier-Stokes Equation for the High Speed Flows, Proceedings of $27^{\text {th }}$ Aerospace Sciences Meeting,AIAA-890283, 1989, pp.1-17.

[7] CHUNG,T.J.: Finite element analysis in fluid dynamics. McGraw-Hill International Book Co., 1978.

[8] CHUNG,T.J.: Computational Fluid Dynamics. Cambridge University Press, Cambridge, UK, 2002.

[9] CLEAR,D.L., DOXBECK,M.: Development of a 3-D Blast Overpressure Modeling Capability Utilizing Fluent. Proceedings of International ANSYS Conference, 2008, pp.1-7.

[10] KURBATSKIII,K.A., MONTANARI,F., CLER,D.L., DOXBECK,M.: Numerical Blast Wave Identification and Tracking Using SolutionBased Mesh Adaptation Approach. AIAA Paper 2007-4188. Proceedings of $18^{\text {th }}$ AIAA Computational Fluid Dynamics Conference, Fluid Dynamics and Co-located Conferences, 2007, pp.1029-1043, DOI: $10.2514 / 6.2007-4188$.

[11] LO,S.H.: Finite Element Mesh Generation. CRC Press, Teylor \& Francis Group, 2015.

[12] CHENG,S.W., DEY,T.K., SHEWCHUK,J.R.: Delaunay Mesh Generation, CRC Press, Florida, 2012.

[13] DANNENHOFFER,J.F.: A comparison of adaptive-grid redistribution and embedding for steady transonic flow. Numerical Methods in Engineering, 1991, Vol.32, No.4, pp.653-663, DOI: 10.1002/nme.1620320403.

[14] PAGE,N.W., Mckelvie,P.I.: Shock Waves Generated by Spark Discharge. Proceedings of $6^{\text {th }}$ Australian Hydraulics and Fluid Mechanic Conference, 1977, pp.221-224 


\title{
Natpritisak oko minobacača od udarnog talasa barutnih gasova
}

\begin{abstract}
Ovaj rad je rezultat dugogodišnjeg istraživanja natpritiska od udarnog talasa barutnih gasova koji se javlja za vreme ispaljivanja iz minobacača. Uzrok ove pojave je nagli izlazak barutnih gasova iz cevi oruđa i njihovo širenje u neporemećenu okolinu. Pokazan je uticaj barutnog punjenja na veličinu natpritiska u blizini minobacača od udarnog talasa barutnih gasova. Istraživanje je obuhvatilo modeliranje i proračun polja natpritiska oko oruđa pri čemu je određen njegov intenzitet i raspodela u prostoru u zavisnosti od vremena. Nakon opisa realne pojave izvršeno je numeričko modeliranje izlaska barutnih gasova iz cevi oruđa. Eksperimentalni rezultati su dobijeni ispaljivanjem iz minobacača kalibra $120 \mathrm{~mm}$. Proračunski i eksperimentalni rezultati dati su u obliku dijagrama promene pritiska na ustima cevi i natpritiska barutnih gasova u karakterističnim mernim tačkama kod minobacača.
\end{abstract}

Ključne reči: dinamika gasova, gasodinamički proces, barutno punjenje,barutni gasovi, natpritisak, udarni talas, uticaj pritiska, minobacač, unutrašnja balistika, eksperimentalni rezultati.

\section{Избыточное давление вокруг минемёта от ударной волны пороховых газов}

\begin{abstract}
Эта работа является результатом многолетних исследований избыточного давления от ударной волны пороховых газов, происходящего во время стрельбы из миномёта. Причиной этого явления является внезапный поток пороховых газов из ствола оружия и их расширение в невозмущённой среде. В работе показано влияние заряда ракетного топлива на интенсивность избыточного давления ударной волны, создаваемой пороховыми газами рядом с миномётом. Исследование включало моделирование и расчёт поля избыточного давления вокруг оружия с целью определения его интенсивности и распределения в пространстве в зависимости от времени. После описания реального явления было проведено численное моделирование выхода пороховых газов из миномётного ствола. Экспериментальные результаты были получены при обжиге из миномёта калибра 120-мм. Вычислительные и экспериментальные результаты приводятся в виде диаграммы изменения давления в стволе и избыточного давления пороховых газов в характерных точках измерения вокруг миномёта.
\end{abstract}

Ключевые слова: динамика газов, процесс газового потока, ракетное топливо, пороховые газы, избыттоное давление, ударная волна, влияние давления, миномёт, внутренняя баллистика, экспериментальные результаты.

\section{Surpression de l'onde de choc des gaz de poudre autour du mortier}

Ce travail est le résultat des recherches de nombreuses années sur la surpression de l'onde de choc des gaz de poudre qui se produit lors du tir du mortier. La cause de ce phénomène est la sortie soudain des gaz de poudre du tuyau du mortier et leur propagation dans l'environnement non perturbé. On a présenté l'influence de la charge de poudre sur l'intensité de la surpression dans le voisinage du mortier qui est causée par l'onde de choc des gaz de poudre. Cette recherche a compris la modélisation et la computation du champ de surpression autour de l'arme afin de déterminer son intensité et sa distribution dans l'espace et dans le temps. Après la description du phénomène réel on a effectué la modélisation numérique de la sortie des gaz de poudre du tuyau du mortier. Les résultats expérimentaux ont été obtenus par le tir du mortier de $120 \mathrm{~mm}$. Les résultats numériques et expérimentaux sont donnés en forme de diagrammes des variations de pression dans la bouche de tuyau et la surpression des gaz de poudre dans les points caractéristiques de mesurage chez le mortier.

Mots clés: dynamique des gaz, processus gaz dynamique, charge de poudre, gaz de poudre, surpression, onde de choc, influence de pression, mortier, balistique intérieure, résultats expérimentaux. 